\title{
Family Dyslipidemia Revealed by a Cornean Bow in a Guinean
}

\author{
Bah Mamadou Bassirou1, Balde El Hadj Yaya1, Balde Alpha Ibrahima², Beavogui Mariame1, \\ Camara Abdoulaye ${ }^{*}{ }^{(1 D}$, Barry Ibrahima Sory ${ }^{1}$, Balde Mamadou Aliou ${ }^{1}$, Sylla Ibrahima Sory 1,2, \\ Kone Alpha ${ }^{3}$, Ngaide Alhassane Aliou ${ }^{4}$, Mamy Adrien${ }^{1}$, Balde Mamadou Dadhi ${ }^{1}$
}

\author{
${ }^{1}$ Ignace Deen National Hospital Cardiology Department, Conakry, Republic of Guinea \\ ${ }^{2}$ Department of Ophthalmology, Department of the Armed Forces, Conakry, Republic of Guinea \\ ${ }^{3}$ Cardiology Department of Donka National Hospital, Conakry, Republic of Guinea \\ ${ }^{4}$ Department of Hospital Cardiology of Grand Yoff, Dakar, Senegal \\ Email: *mariboudou@gmail.com
}

How to cite this paper: Bassirou, B.M., El Hadj Yaya, B., Ibrahima, B.A., Mariame, B., Abdoulaye, C., Sory, B.I., Aliou, B.M., Sory, S.I., Alpha, K., Aliou, N.A., Adrien, M. and Dadhi, B.M. (2020) Family Dyslipidemia Revealed by a Cornean Bow in a Guinean. World Journal of Cardiovascular Diseases, $10,455-459$.

https://doi.org/10.4236/wjcd.2020.107045

Received: March 29, 2020

Accepted: July 17, 2020

Published: July 20, 2020

Copyright $\odot 2020$ by author(s) and Scientific Research Publishing Inc. This work is licensed under the Creative Commons Attribution International License (CC BY 4.0).

http://creativecommons.org/licenses/by/4.0/ (c) (i) Open Access

\begin{abstract}
Object: The aim of this study was to describe a familial dyslipidemia revealed by a corneal arch. Familial hypercholesterolemia is a rare and severe hereditary dyslipidemia with an exceptional homozygous form. $\mathrm{He}$ was a 43-year-old patient admitted with visual disturbance, xanthomatous papule and orange coloring at the level evolving for 5 years, no personal history of cardiovascular disease, having a family history of lipid disorders in siblings, as a cardiovascular risk factor: age over 50 and the male gender, normal cardio pulmonary examination, blood pressure at $120 / 80 \mathrm{mmhg}$, heart rate $78 \mathrm{bpm}$, in whom the ophthalmological examination shows a yellowish spot on the cornea (Figure 1). We report the case of familial dyslipidemia revealed by a corneal spot in Guinea. More recent studies increasingly suggest that it is much more widespread than previously thought: 1/200 to 1/400. Familial dyslipidemia is a rare and severe metabolic abnormality. It should be screened as early as possible like any other cardiovascular risk factor for atheroma to avoid the occurrence of a major cardiovascular event.
\end{abstract}

\section{Keywords}

Corneal Arch, Familial Dyslipidemia, Guinea

\section{Introduction}

Familial hypercholesterolemia is a rare and severe hereditary dyslipidemia with an exceptional homozygous form [1]. The lack of LDL receptors or suitable receptors explains their accumulation in the plasma and the acceleration of the 
formation of atherosclerosis. It is a very rare pathology ( $1 \%$ of hypercholesterolaemia and 1/106 hbts in the USA) which causes $100 \%$ mortality at 30 years according to BAKER SG [2]. It is responsible for severely high cholesterol levels (> $300 \mathrm{mg} / \mathrm{dl}$ ) from birth and for a dramatically early risk of vascular, cardiac or cerebral complications from the age of 30 in men, and 40 in women [3]. With early diagnosis and adequate treatment, ideally started in childhood, it is possible to avoid any cardiovascular complications [3]. The aim of this study was to describe a familial dyslipidemia revealed by a corneal arch.

\section{Observation}

He was a 43-year-old patient admitted for a visual disorder, xanthomatous papule and orange discoloration at the level of the folds, evolving for 5 years. No personal history of cardiovascular disease, having a family history of lipid disorders in siblings. As a cardiovascular risk factor: age over 50 and the male gender. The cardio pulmonary examination is normal, blood pressure at 120/80 mmhg, heart rate $78 \mathrm{bpm}$. In whom the ophthalmological examination shows a corneal arch at eye level (Figure 1). The ankle/arm systolic pressure index (PSI) was 1 on the right and 0.9 on the left. The anatomical examination of the skin revealed a histological appearance compatible with a cutaneous xanthoma. Biology showed a total cholesterol level of $7.70 \mathrm{~g} / \mathrm{l}$ (normal value $<2 \mathrm{~g} / \mathrm{l}$ ); triglycerides at $4.81 \mathrm{~g} / \mathrm{l}$ (normal value $<1.5 \mathrm{~g} / \mathrm{l}$ ); HDL level at $0.21 \mathrm{~g} / 1$ (normal value $>$ $0.4 \mathrm{~g} / \mathrm{l})$. Electrocardiogram and transthoracic doppler echocardiography were normal. In the supra-aortic trunk eco doppler, the intima media thickness was $0.85 \mathrm{~mm}$ on the right and $0.80 \mathrm{~mm}$ on the left.

At the end of the clinical and para-clinical examination, the diagnosis of familial dyslipidemia was retained according to the diagnostic criteria of the Dutch Lipid Clinic Network takes into account LDL-C levels, personal and/or family history and clinical signs that may be present in some patients [4]. The diagnosis is based on the total number of points obtained: "certain" if $>8$ points; "Likely" if 6 - 8 points; "Possible" if 3 - 5 points. [4]. The patient had totaled more than 8 points making certain the diagnosis of dyslipidemia with familial hypercholesterolemia type as indicated in Table 1. The patient benefited from a statin for one year with success, with a total cholesterol control rate of $2.3 \mathrm{~g} / \mathrm{l}$.

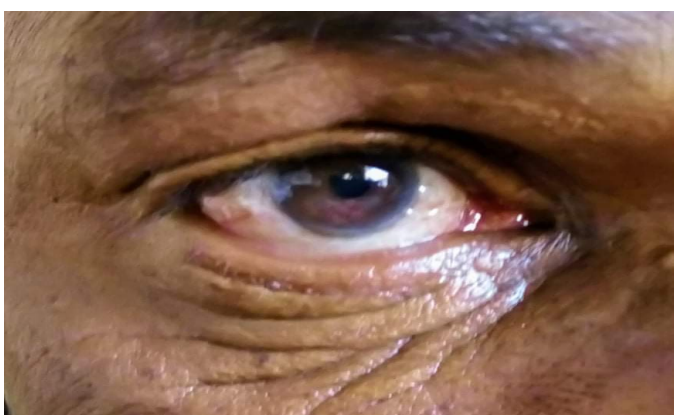

Figure 1. Showing a corneal arch. 
Table 1. Clinical diagnostic criteria for familial hypercholesterolaemia in adults according to the Dutch lipid clinic network diagnostic criteria [4].

\begin{tabular}{|c|c|}
\hline CRITERIA & POINTS \\
\hline \multicolumn{2}{|l|}{ Family history } \\
\hline $\begin{array}{l}\text { A first degree member with early cardiovascular disease } \\
(\mathrm{M}<55 \text { years old; } \mathrm{W}<60 \text { years old) or a first degree member with } \mathrm{LDL}-\mathrm{C}>190 \mathrm{mg} / \mathrm{dl}\end{array}$ & 1 \\
\hline $\begin{array}{l}\text { A first degree member with tendon xanthomas or corneal arches or a child under } 18 \\
\text { with LDLC }>135 \mathrm{mg} / \mathrm{dl}\end{array}$ & 2 \\
\hline \multicolumn{2}{|l|}{ Personal history } \\
\hline Patient with early coronary artery disease $(\mathrm{M}<55$ years old; $\mathrm{F}<60$ years old $)$ & 2 \\
\hline Patient with early cerebral or peripheral vascular disease & 1 \\
\hline \multicolumn{2}{|l|}{ Examen Clinique } \\
\hline Xanthomes tendineux & 6 \\
\hline Corneal arch before 45 & 4 \\
\hline \multicolumn{2}{|l|}{ LDL-C level (before any treatment) } \\
\hline $\mathrm{LDL}-\mathrm{C} \geq 330 \mathrm{mg} / \mathrm{dl}$ & 8 \\
\hline LDL-C between 250 and $329 \mathrm{mg} / \mathrm{dl}$ & 5 \\
\hline LDL-C between 190 and $249 \mathrm{mg} / \mathrm{dl}$ & 3 \\
\hline LDLC between 150 and $189 \mathrm{mg} / \mathrm{dL}$ & 1 \\
\hline \multicolumn{2}{|l|}{ TEST GENETIQUE } \\
\hline Mutation on the LDL-R, APOB or PCSK-9 gene & 8 \\
\hline
\end{tabular}

H: Man; W: woman.

\section{Discussion}

We report the case of familial dyslipidemia revealed by a corneal arch in Guinea.

More recent studies increasingly suggest that it is much more widespread than previously thought: $1 / 200$ to $1 / 400$. Familial hypercholesterolemia (HF) is caused by the presence of a single mutated allele (heterozygous state) of the LDLR genes, coding for the receptor LDL, APOB coding for the apolipopotein B responsible for the binding between LDL particles and their receptor [5] which facilitates lysosomal degradation of LDL receptors) [6]. Cholesterol is thus deposited in the arterial walls leading to early cardiovascular complications [3]. They are also typically deposited in other tissues producing the appearance of corneal arches and tendon xanthomas which are nodules on the tendons of the hands or on the Achilles tendons [3]. Our patient presented with xanthomas and a corneal arch. In adults, it is possible to make the diagnosis with more certainty on the basis of the criteria of the Dutch Lipid Clinic Network (Table 1), which take into account LDL-C levels, personal history and/or family history and clinical signs that may be present in some patients [4]. The diagnosis is based on the total number of points obtained: "certain" if $>8$ points; "Likely" if $6-8$ points; "Possible" if 3 - 5 points. [4]. Our case had more than 8 points making the diagnosis of familial hypercholesterolemia dyslipidemia certain. Any individual with 
familial dyslipidemia will not develop cardiovascular complications at the same rate, the progression of atherosclerosis dependent on the mutation, the family history and additional risk factors [7] [8]. The genetic test was not performed due to lack of an adequate laboratory, did not present a sign suggesting a cardiovascular complication. Observational studies have confirmed the benefit of lipid-lowering treatment in adults [9] but also in children [10]. Our case is a perfect illustration of this literature because at one year from the flow of statin administration, the total cholesterol control rate returned to $2.3 \mathrm{~g} / \mathrm{l}$. The patient is currently being followed in the department without any complications from dyslipidemia.

\section{Conclusion}

Familial dyslipidemia is a rare and severe metabolic abnormality. It should be screened as early as possible like any other cardiovascular risk factor for atheroma to avoid the occurrence of a major cardiovascular event.

\section{Conflicts of Interest}

The authors declare no conflicts of interest regarding the publication of this paper.

\section{References}

[1] Zermouni, R., Tadmori, A.E., Touzani, A. and Gaouzi, A. (2014) Homozygous Familial Hypercholesterolaemia: About a Case.

[2] Baker, S.G., Joffe, B.I., Mendelsohn, D. and Seftel, H.C. (1982) Treatment of Homozygous Familial Hypercholesterolemia with Probucol. South African Medical Journal, 62, 7-11.

[3] Descamps, O.S. (2016) Hypercholestérolémie familiale louvain med.

[4] Nordestgaard, B.G., Chapman, M.J., Humphries, S.E., Ginsberg, H.N., Masana, L., Descamps, O.S., et al. For the European Atherosclerosis Society Consensus Panel (2013) Familial Hypercholesterolaemia Is Underdiagnosed and Undertreated in the General Population: Guidance for Clinicians to Prevent Coronary Heart Disease: Consensus Statement of the European Atherosclerosis Society. European Heart Journal, 34, 3478-3490. https://doi.org/10.1093/eurheartj/eht273

[5] Goldstein, J.L., Hobbs, H.H. and Brown, M.S. (2001) Familial Hypercholesterolemia. In: Scriver, C.R., Sly, W.S., Childs, B., et al., Eds., The Metabolic and Molecular Bases of Inherited Disease, 8th Edition, McGraw-Hill Companies Inc., New York, NY.

[6] Seidah, N.G., Benjannet, S., Wickham, L., Jasmin, S.B., Stifani, S., Basak, A., et al. (2003) The Secretory Proprotein Convertase Neural Apoptosis-Regulated Convertase 1 (NARC-1): Liver Regeneration and Neuronal Differentiation. Proceedings of the National Academy of Sciences of the United States of America, 100, 928-933. https://doi.org/10.1073/pnas.0335507100

[7] Nordesgaard, B., et al. (2010) Lipoprotein(a) as a Cardiovascular Risk Factor: Current Status. European Heart Journal, 31, 2844-2853. https://doi.org/10.1093/eurheartj/ehq386

[8] Gidding, S.S., et al. (2015) The Agenda for Familial Hypercholesterolemia: A Scien- 
tific Statement from the American Heart Association. Circulation, 132, 2167-2192. https://doi.org/10.1161/CIR.0000000000000297

[9] Versmissen, J., Oosterveer, D.M., Yazdanpanah, M., Defesche, J.C., Basart, D.C., Liem, A.H., et al. (2008) Efficacy of Statins in Familial Hypercholesterolaemia: A Long Term Cohort Study. BMJ, 337, a2423. https://doi.org/10.1136/bmj.a2423

[10] Wiegman, A., Gidding, S.S., Watts, G.F., Chapman, M.J., Ginsberg, H.N., Cuchel, M., et al. for the European Atherosclerosis Society Consensus Panel (2015) Familial Hypercholesterolaemia in Children and Adolescents: Gaining Decades of Life by Optimizing Detection and Treatment. European Heart Journal, 36, 2425-2437. https://doi.org/10.1093/eurheartj/ehv157 